\title{
慢性剝離性歯肉炎患者の臨床的, 病理学的および細菌学的研究
}

$$
\begin{aligned}
& \text { 上田雅俊寺西義浩 中垣直毅 } \\
& \text { 山岡昭井上純一* 久米満* } \\
& \text { 尾上孝利* 福島久典* 佐川寛典* } \\
& \text { 田中淳 司**田中昭 男** } \\
& \text { 大阪歯科大学歯周病学講座 } \\
& \text { (主任：山岡 昭教授) } \\
& \text { *大阪歯科大学細菌学教室 } \\
& \text { （主任：佐川寬典教授） } \\
& \text { **大阪歯科大学口腔病理学講座 } \\
& \text { (主任：田中昭男教授) } \\
& \text { (平成 } 3 \text { 年 } 9 \text { 月 } 13 \text { 日受付) }
\end{aligned}
$$

\section{Clinical, Histopathological and Bacteriological Study of Chronic Desquamative Gingivitis}

\author{
Masatoshi UEDA, Yoshihiro TERANISHI, Naoki NAKAGAKI, \\ Akira YAMAOKA, Jun-ichi INOUE*, Mitsuru KUME*, \\ Takatoshi ONOE*, Hisanori FUKUSHIMA*, Hirosuke SAGAWA*, \\ Junji TANAKA** and Akio TANAKA** \\ Department of Periodontology, Osaka Dental University \\ 5-31, Otemae 1-chome, Chuo-ku, Osaka 540, Japan \\ (Chief : Prof. Akira YAMAOKA) \\ *Department of Bacteriology, Osaka Dental University \\ (Chief : Prof. Hirosuke SAGAWA) \\ **Department of Oral Pathology, Osaka Dental University \\ (Chief : Prof. Akio TANAKA)
}

\begin{abstract}
Clinical, histopathological and bacteriological aspects of chronic desquamative gingivitis were studied in afflicted patients. Clinically, there was a deteriorative stage in which the gingiva showed marked epithelial exfoliation with a glossy erythematous appearance, and a remissive stage in which these features abated, the two stages showing peri odic alteration. Histopathologically, the parakeratinized epithelium was thinned, with short or absent rete pegs, and inflammatory cell infiltration was
\end{abstract}

evident in epithelial intercellular spaces ; extensive lymphocyte infiltration was seen beneath the epithelium. There was also hydropic change in the basal cell layer and micro-bulla formation beneath the epithelium. Electron microscopically, amorphous substances were observed in the space created by separation of basal cells and the basal lamina. The basal lamina showed tearing, and desmosomes were decreased in number. Bacteriologically, there was no correlation between the deteriorative 
and remissive stages with regard to bacterial counts, proportional distribution of gram- positive and gram-negative bacteria, or colony counts of bacteria from saliva, gingival crevicular fluid, tongue plaque, and periodontal pockets.

Key words : Chronic desquamative gingivitis, Clinical findings, Histopathological findings, Bacteriological findings

要旨: 慢性剝離性歯肉炎患者について, 臨床的, 病理組織学的および細菌学的に検討した結果, つぎの結論を得 た。すなわち, 臨床的には, 歯肉の上皮が剝離し, 光沢をおび鮮紅色を呈する増悪期と, 比較的その症状の軽減し た緩解期とを，ある周期をもって繰り返していた。病理組織学的に，上皮突起は扁平化をきたし，錯角化を呈した 上皮組織は薄くなり，上皮細胞間隙に炎症細胞，そして上皮下には著しいリンパ球の浸潤が認められた。基底細胞 層に水症性変化が，そして上皮下に微小水疮の形成がみられた。電顕的に，上皮細胞間隙および基底細胞と基底板 が分離した間に, amorphous substance が認められた。また, 基底板の断裂やデスモソームの数の減少がみられた。 細菌学的には, 唾液, 歯肉溝滲出液, 舌苔およびポケット内の歯垢の緩解期と増悪期における細菌数, 酸素要求性 および細胞形態による細菌分布を比較すると，両時期の間に一定の傾向はみられなかった。

索引用語：慢性剝離性歯肉炎, 臨床的観察, 病理組織学的観察, 細菌学的観察

\section{緒言}

慢性剝離性歯肉炎は，歯肉上皮に繰り返し剥離を起 こす歯肉疾患であり，臨床的には，同一患者であって も部位あるいは時期によりさまざまな症状を呈する。 とくにその周期は一定しないが, ほとんどの症例では, 臨床症状の緩解期と増悪期とを繰り返すとされてい る。本症の原因はまだ解明されていないが，一般的に は全身的な原因によって歯肉の結合組織や上皮に退行 性変化が起こり，二次的に局所の炎症が合併した疾患 であると考えられている ${ }^{1 \sim 7)}$ 。しかし, 近年, 免疫学的 研究の進歩により, 自己免疫的要因の存在が確認され つつあるけれども ${ }^{8 \sim 10)}$, 臨床の実際では, プラークコン トロールをすることにより, 症状の改善が認められる 症例が少なくない。したがって,なんらかの形でプラー クが症状の増悪に関与しているものと考えられるし, また, その臨床症状の緩解期および増悪期により細菌 叢が異なるのではないかと思われる。

そこで, 今回, 私達は以下のような臨床的, 病理組 織学的, および細菌学的観察を行い若干の知見を得た ので報告する。

\section{被験者および観察方法}

\section{1. 被 験 者}

被験者は, 大阪歯科大学附属病院歯周病科外来を訪 れた患者のうち，慢性剥離性歯肉炎と考えられる患者
2 名である。

\section{2. 観察方法}

1) 臨床的観察

歯肉の疼痛あるいは灼熱感など患者の自覚症状と歯 肉の発赤, すなわち, 剝離傾向などの他覚症状を総合 的に判定し，緩解期および増悪期を決定した。なお， その判定の際には, 口腔内写真も参考とした。

\section{2) 病理組織学的観察}

歯肉の biopsy を行い, 採取した歯肉を 2 分割し， 1 つは光顕用に $10 \%$ ホルマリンで固定して通法により パラフィン切片を作製し，ヘマトキシリン・エオジン 染色を施し検鏡した。また，他の 1 つは，電顕用に $\mathrm{pH} 7.3$ の $0.1 \mathrm{M}$ カコジル酸緩衝の $2.5 \%$ グルタルア ルデヒドと $2 \%$ パラホルムアルデヒド混合液で $4{ }^{\circ} \mathrm{C}, 2$ 時間前固定を行い, 同緩衝液で洗浄し, 同緩衝の $1 \%$ オ スミウム酸で $4^{\circ} \mathrm{C}, 1$ 時間後固定した。その後, 通法に より Poly/Bed 812 に包埋し, 準超薄および超薄切片 を作製し，それぞれトルイジンブルー染色および酢酸 ウラニルとクエン酸鉛の二重染色を施し，光䫓的およ び日立 $\mathrm{H}-800$ 型透過電子顕微鏡により検索した。

\section{3) 細菌学的観察}

唾液, 歯肉溝滲出液, 舌苔およびポケット内の歯垢 を嫌気的に採取し, reduced transport fluid (RTF) を用いて，嫌気 box 内に輸送した。採取試料は 10 倍連 続希釈後, 各希釈液を $\mathrm{CDC}$ 処方の $5 \%$ 血液寒天培地 および選択培地に塗抹した。その後, 嫌気培養は 7 日 間, 好気培養は 2 日間行った。培養後, 血液寒天培地 の総菌数およびコロニー形態を観察し，好気および嫌 


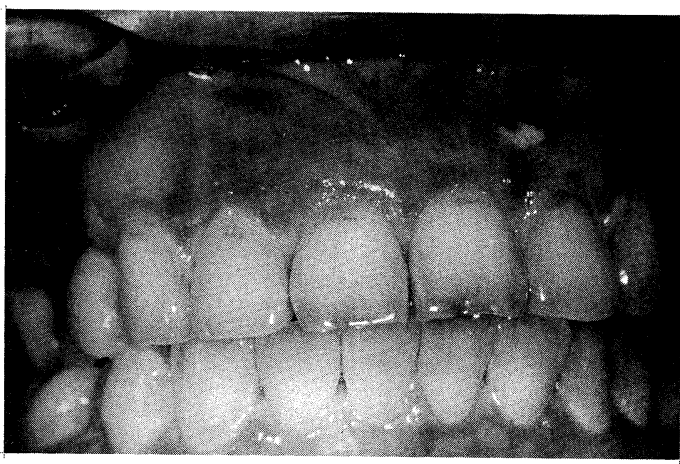

図 1 症例 1 の口腔内写真（増悪期）

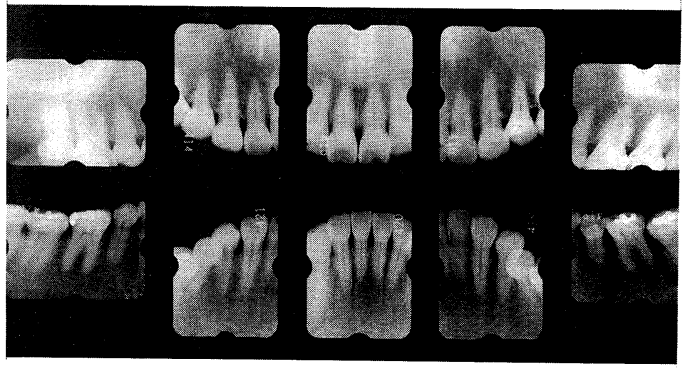

図 2 症例 1 の初診時のX線写真

気テストを行い, 偏性嫌気性菌, 通性嫌気性菌および 好気性菌を区別した。一方, 選択培地からはコロニー 形態, 配列, 細胞形態扔よびグラム染色性を観察し, 目的とするコロニー数を算定した。

\section{結 果}

\section{1. 臨床的観察結果}

1) 症 例 1

図 1 は現在 58 歳の女性で, 1990 年 6 月 20 日, 歯肉 の疼痛を主訴として来院した患者の病態写真である。 約 2 年程前より，歯肉の剝離傾向に気づいていたが, 放置していたとのことであった。来院の 1 週間前より, 歯肉に灼熱様の疼痛があり，某歯科医院を訪れ，洗浄 などの処置を受けていたが，状態に変化がなかったと いうことであった。臨床的には，上皮は剝離し，辺縁 歯肉のみならず，付着歯肉も光沢をおび，鮮紅色を呈 していた。この剥離傾向は, 全顎にわたっての唇側およ び煩側のみで，舌側および口蓋側には認められなかっ た。このような症状の時期を，一応，増悪期とした。

図 2 は初診時のX線写真であるが，上下顎前歯部に わずかな骨吸収が認められる程度であった。

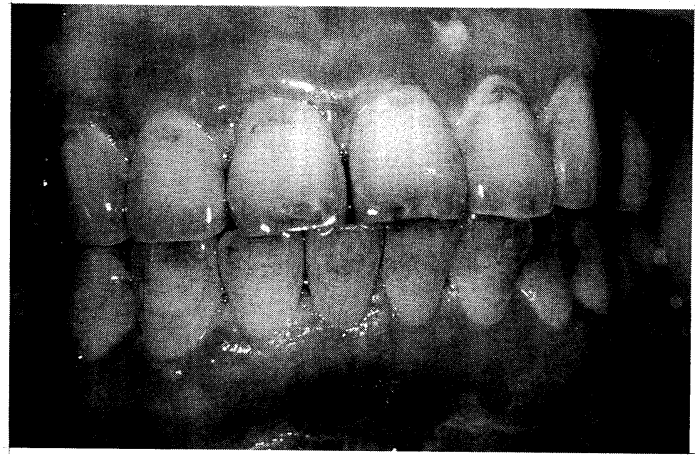

図 3 症例 1 の口腔内写真（緩解期）

この患者に，主とてプラークコントロールなどの初 期治療を施しながら経過観察し, 緩解期と思われる時 期の病態写真が，図 3 である。前述の増悪期と比較す ると，光沢をおびた鮮紅色の範囲も狭く，また，その 色の鮮明さも失われており，やや正常像に近いピンク 色を呈していた。この患者については，約 1 年経過観 察を行っているが，約 1 カ月半の周期で緩解期と増覀 期を繰り返している。

2) 症 例 2

現在 52 歳の女性で, 1990 年 6 月 29 日, 症例 1 と同 様に歯肉の疼痛を主訴として来院した患者である。 1988 年より歯肉の剥離傾向がみられ, 本院に来院して 治療を行っていたが，約半年ほど通院後，中断した。 症状に変化はなく，そのまま放置していた既往歴があ る。2，3 日前より灼熱様の疼痛があり，再び来院した。 この症例では，図 4 のように前歯部においては，主と して, 辺緑歯肉のみが上皮剝離を示し，鮮紅色を呈し， 光沢をおびており，付着歯肉には，そのような症状は あまり認められなかったが，左右臼歯部には，付着歯 肉にも剝離傾向が認められた。このような症状の時期 を一応増悪期とした。

図 5 は初診時のX線写真であるが，この症例も下顎 前歯部に骨吸収がやや認められる程度であった。

この症例の緩解期と思われる臨床写真は図 6 であ る。前歯部および曰歯部ともに，前述の増悪期と比較 すると，辺縁歯肉および付着歯肉の光沢をおびた鮮紅 色の範囲が狭まってきていた。この患者では 1 力月程 度の周期をもって緩解期と増悪期を繰り返していた。

\section{2. 病理組織学的観察結果}

症例 1 のへマトキシリン・エオジン染色標本（図 7 ) では，上皮突起は扁平化をきたして上皮組織は薄くな り，また，過錯角化の立進があり，上皮下には著しい 


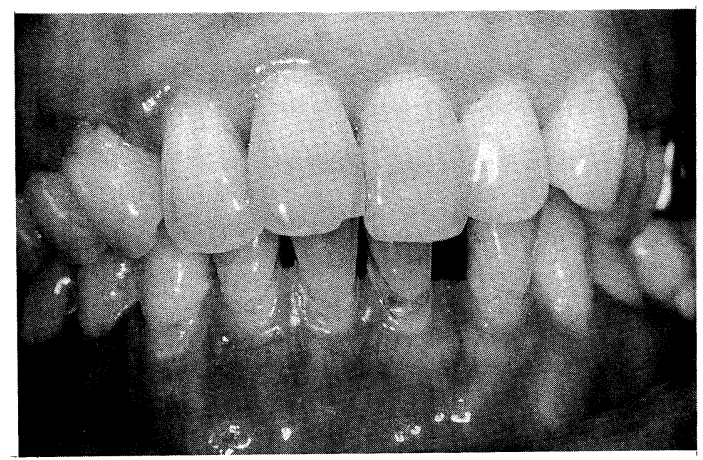

図 4 症例 2 の口腔内写真（増悪期）

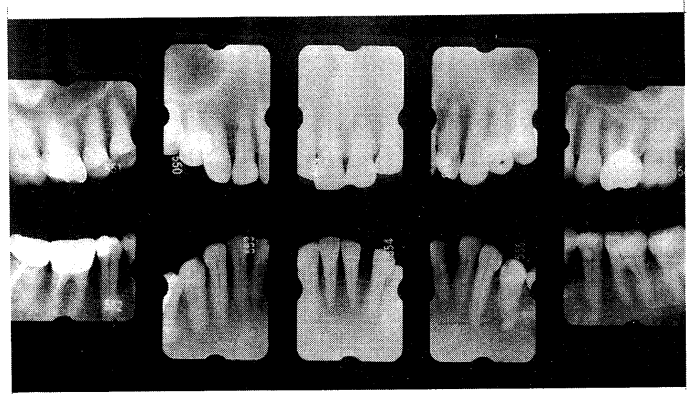

図 5 症例 2 の初診時のX線写真

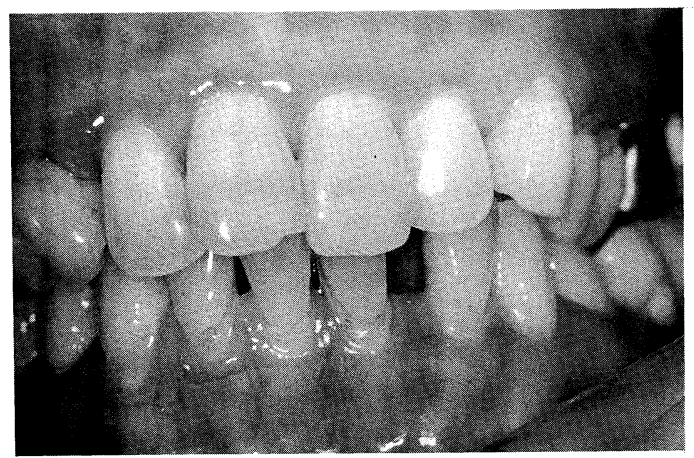

目 6 症例 2 の口腔内写真（緩解期）

リンパ球の浸潤が認められた。基底細胞層付近の細胞 間隙は拡張し，軽度の出血やリンパ球がみられた。

薄くなった上皮の直下に好中球や単核球を含む微小 な水疮がみられた（図 8 )。

症例 1 の電顕標本（図 9 ）では，上皮細胞間隙に好 中球やリンパ球様細胞, amorphous substance がみら れ，基底板は基底細胞から分離し，その間にも amorphous substance が認められた。また, 基底細胞層付近 の細胞にはデスモソームの数の減少がみられた。上皮 細胞間隙や基底細胞と分離した基底板の間にも amor-

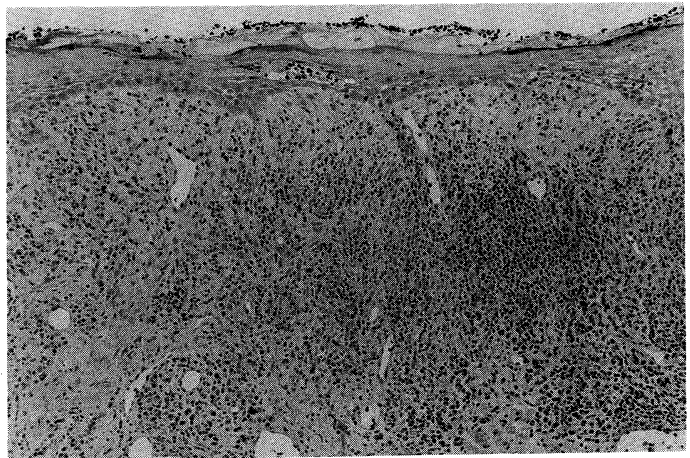

図 7 上皮突起は扁平化をきたして上皮組織は薄く なり，過錯角化の克進拉よび上皮下への著し いリンパ球の浸潤が認められる(症例 $1, \mathrm{H}$ $\& \mathrm{E}$ 染色， $\times 98 ）$

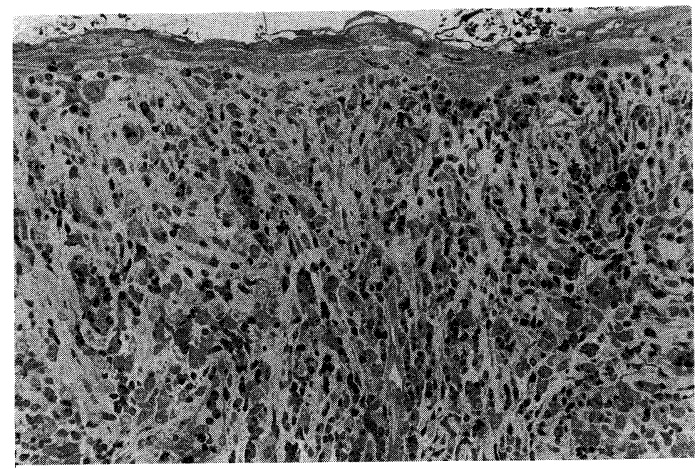

図 8 基底細胞層付近の細胞間隙は拡張し, 軽度の 出血やリンパ球が認められ，薄くなった上皮 の直下に好中球や単核球を含む微小な水疮が みられる（症例 1, トルイジンブルー染色， $\times 196)$

phous substance が認められ，基底板は不連続になっ ていた。基底細胞に多数の空胞が認められ，この細胞 にはハーフデスモソームはあるが，基底板は断裂し， 一部は細胞から分離していた。基底板は基底細胞の細 胞膜と接していたが，大部分は分離していた（図 10)。 また，上皮下結合組織にはリンパ球を主体とする炎症 細胞浸潤があり，一部のリンパ球の核は不規則になっ ていた。

症例 2 のトルイジンブルー染色標本では, 上皮の過 角化ならびに上皮突起の扁平化がみられ，上皮下には リンパ球を主体とする炎症細胞がビマン性に浸潤して いた（図 11）。 


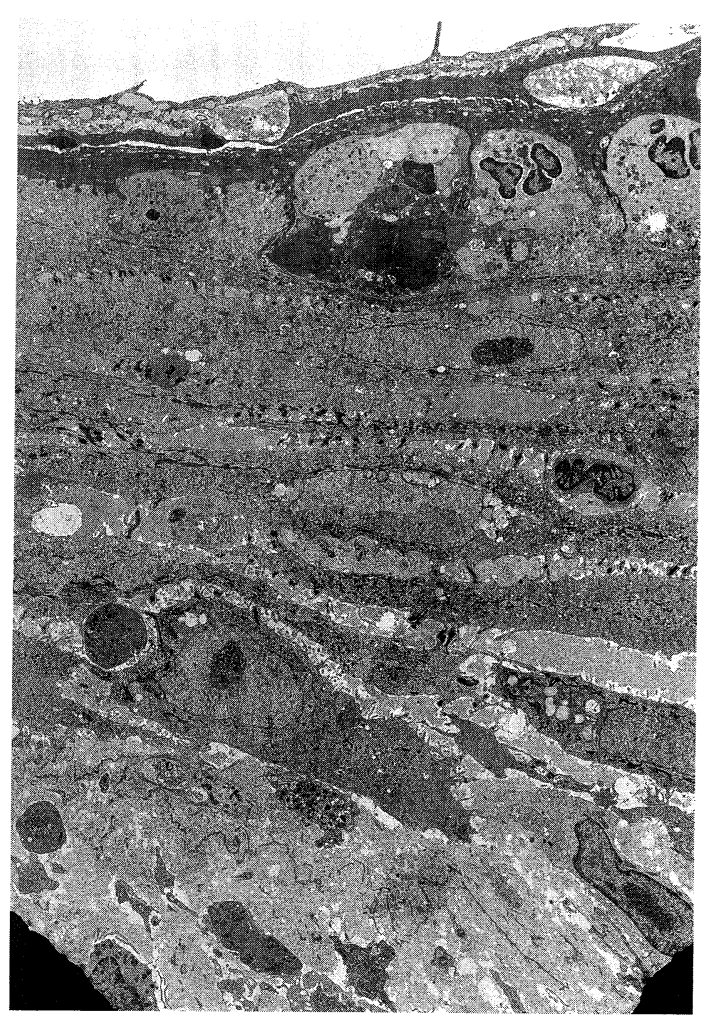

図 9 上皮細胞間吵に好中球やリンパ球様細胞, amorphous substanceがみられ, 基底板は基 底細胞から分離し、その間にも, amorphous substance が認められる。また, 基底細胞層 付近の細胞にはデスモソームの数の減少がみ られる（症例 $1, \times 2,400 ）$

\section{3. 細菌学的観察結果}

表 1 は唾液の緩解期と増悪期における唾夜 $1 \mathrm{~m} l$ 中 の細菌数を示したものである。両時期の間には関連性 はなかった。

表 2 は唾液, 表 3 は舌苔それぞれの酸素要求性およ び細胞形態で, 緩解期および増悪期の細菌分布を示し たものである。両時期を比較すると, 両症例を通じて, 数值の変化が認められたが, 一定した変化は示さな かった。ただ，増悪期になると，好気性菌が若干増え る傾向にあった。

表 4 は唾夜, 表 5 は歯周ポケットにおける菌種を示 したものである。両者ともに, 緩解期と増悪期を比較 すると, 両症例ともに, 分離される菌種と菌数に変化 はみられたが, 一定の傾向は認められなかった。

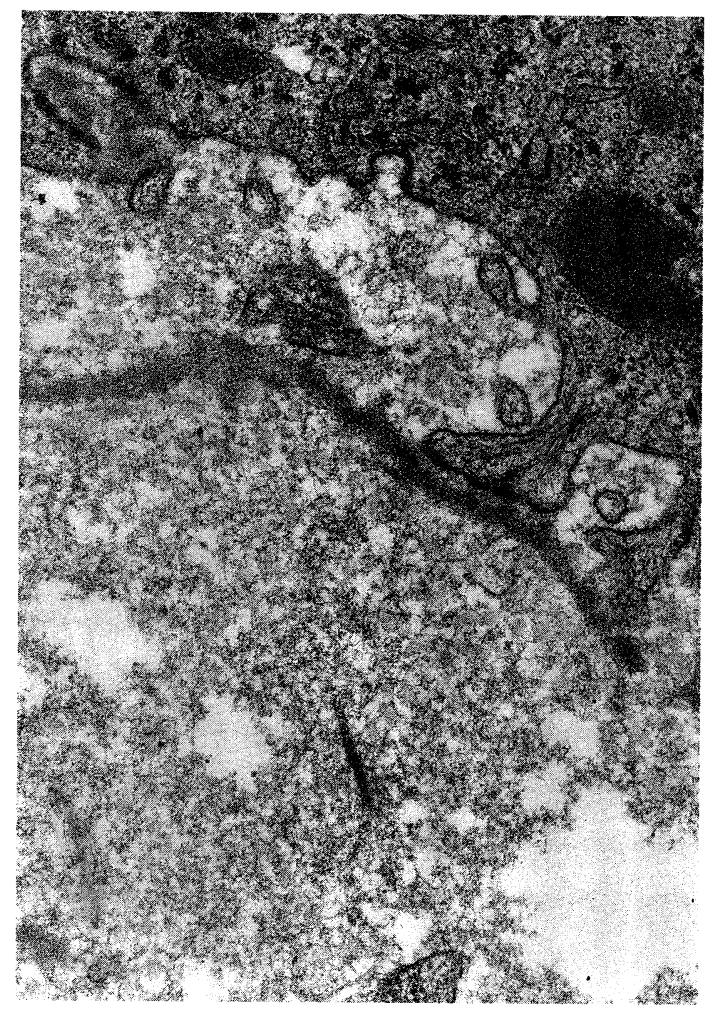

図 10 一部の基底板は基底細胞の細胞膜と接して いるが，大部分は分離している（症例 1 , $\times 43,000)$

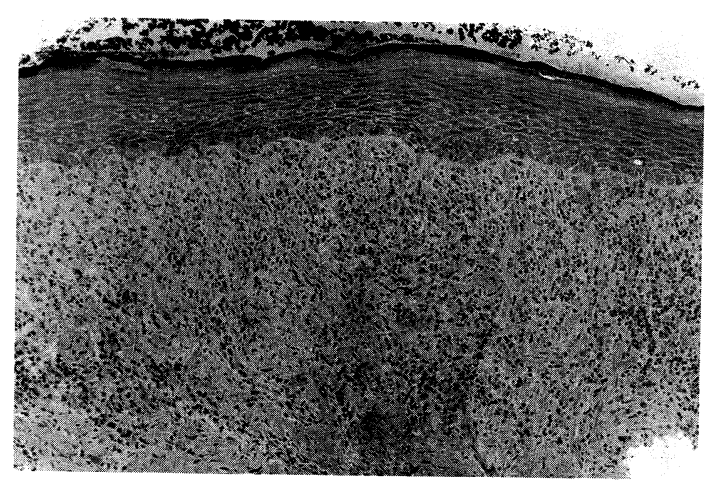

図 11 上皮の過角化ならびに上皮突起の扁平化が みられ，上皮下にはリンパ球を主体とする 炎症細胞がビマン性に浸潤している（症例

2, トルイジンブルー染色, $\times 98)$ 
表 1 緩解期と増覀期における唾液 $1 \mathrm{~m} l$ 中の細菌数

\begin{tabular}{lcccc}
\hline & \multicolumn{2}{c}{ Case 1 } & \multicolumn{2}{c}{ Case 2 } \\
& Remissive s. ${ }^{*}$ & Deteriorative s. ${ }^{* *}$ & Remissive s. $^{*}$ & Deteriorative s. $^{* *}$ \\
\hline Aerobic & $1.2 \times 10^{8}$ & $1.4 \times 10^{8}$ & $7.1 \times 10^{7}$ & $3.2 \times 10^{7}$ \\
Anaerobic & $3.2 \times 10^{8}$ & $8.4 \times 10^{7}$ & $1.6 \times 10^{8}$ & $8.0 \times 10^{8}$ \\
\hline
\end{tabular}

${ }^{*}$ Remissive stage ${ }^{* *}$ Deteriorative stage

表 2 緩解期と増悪期における酸素要求性および細胞形態での細菌分布 (唾液)

\begin{tabular}{|c|c|c|c|c|}
\hline & \multicolumn{2}{|c|}{ Case 1} & \multicolumn{2}{|c|}{ Case 2} \\
\hline & Remissive s. & Deteriorative s. & Remissive s. & Deteriorative s. \\
\hline Anaerobes & & & & $(\%)$ \\
\hline \multicolumn{5}{|l|}{ Gram positive } \\
\hline cocci & 2.5 & 8.0 & 4.4 & 4.8 \\
\hline rods & 17.7 & 6.0 & 11.9 & 8.3 \\
\hline \multicolumn{5}{|l|}{ Gram negative } \\
\hline cocci & 2.5 & 7.0 & 11.9 & 26.2 \\
\hline rods & 8.9 & 9.0 & 14.4 & 8.3 \\
\hline \multicolumn{5}{|l|}{ Facultatives } \\
\hline \multicolumn{5}{|l|}{ Gram positive } \\
\hline cocci & 12.7 & 13.0 & 15.6 & 7.1 \\
\hline rods & 43.4 & 28.0 & 26.7 & 15.5 \\
\hline \multicolumn{5}{|l|}{ Gram negative } \\
\hline cocci & 6.3 & 6.0 & 8.8 & 21.4 \\
\hline rods & 5.1 & 6.0 & 6.3 & 3.6 \\
\hline \multicolumn{5}{|l|}{ Aerobes } \\
\hline \multicolumn{5}{|l|}{ Gram positive } \\
\hline cocci & & 1.0 & & \\
\hline rods & 0.9 & 1.0 & & \\
\hline \multicolumn{5}{|l|}{ Gram negative } \\
\hline cocci & & 15.0 & & 4.8 \\
\hline rods & & & & \\
\hline
\end{tabular}

\section{考 察}

慢性剝離性歯肉炎は，歯周疾患のなかで特殊歯周疾 患に入れられており，原因因子も不明で，したがって， 確立した治療法もなく, 難病とされている ${ }^{1,2)}$ 。また,

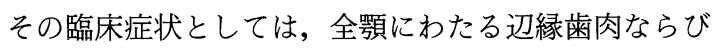
に付着歯肉などの歯肉全体に剝離傾向をあらわすも の, あるいは全顎ではなく, しかも辺緑歯肉のみにそ の傾向があるものなどさまざまである。しかしながら， いずれの場合も周期の差こそあれ, 臨床症状の緩解期 と増悪期とを繰り返すことは経験的に知られていると ころである。また，プラークをコントロールすること により, 臨床症状の改善が認められる症例も多く, し
たがって，なんらかの形でプラークが，その症状の発 現に関与しているものと考えられるし, 前述の臨床症 状の緩解期および増悪期により細菌叢が異なることに もつながると思われる。

そこで, 本実験では, 従前より行われてきている本 患者を臨床的に, 歯肉の biopsy を行い光顕的および電 顕的に, そして唾液, 歯肉溝滲出液, 舌苔およびポケッ 卜内の歯垢を細菌学的に，それぞれ観察することに よって検討した。

その結果, 臨床的に, 症例 1 の増悪期では, 唇側お

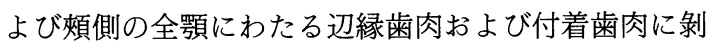
離傾向があり, 光沢をおび, 鮮紅色を呈していた。ま た, 緩解期では, 増悪期と比較すると, 光沢をおびた 鮮紅色の範囲も狭く, また, その色の鮮明さも失われ 
表 3 緩解期と増悪期における酸素要求性および細胞形態での細菌分布（舌苔）

Case $1 \quad$ Case 2

Remissive s. Deteriorative s. Remissive s. Deteriorative s.

\begin{tabular}{|c|c|c|c|c|}
\hline Anaerobes & & & & (\%) \\
\hline \multicolumn{5}{|l|}{ Gram positive } \\
\hline $\operatorname{cocci}$ & 5.9 & & 4.4 & 4.5 \\
\hline rods & 21.2 & 1.2 & 27.3 & 1.8 \\
\hline \multicolumn{5}{|l|}{ Gram negative } \\
\hline cocci & 2.4 & & 28.7 & 11.6 \\
\hline rods & 10.6 & 4.2 & 17.4 & 16.1 \\
\hline \multicolumn{5}{|l|}{ Facultatives } \\
\hline \multicolumn{5}{|l|}{ Gram positive } \\
\hline $\operatorname{cocci}$ & 23.5 & 1.8 & 4.4 & 16.1 \\
\hline rods & 24.7 & 34.5 & 13.4 & 22.1 \\
\hline \multicolumn{5}{|l|}{ Gram negative } \\
\hline cocci & 3.5 & 5.5 & 1.5 & 11.6 \\
\hline rods & 8.2 & 25.5 & 2.9 & 16.1 \\
\hline \multicolumn{5}{|l|}{ Aerobes } \\
\hline \multicolumn{5}{|l|}{ Gram positive } \\
\hline $\operatorname{cocci}$ & & 5.5 & & \\
\hline rods & & 1.8 & & 5.4 \\
\hline \multicolumn{5}{|l|}{ Gram negative } \\
\hline $\operatorname{cocci}$ & & 20.0 & & 6.3 \\
\hline rods & & & & \\
\hline
\end{tabular}

表 4 緩解期と増悪期における菌種（唾液）

\begin{tabular}{lcccc}
\hline & \multicolumn{2}{c}{ Case 1 } & \multicolumn{2}{c}{ Case 2} \\
& Remissive s. & Deteriorative s. & Remissive s. & Deteriorative s. \\
\hline Bifidobacterium & & $2.1 \times 10^{5}$ & & $2.0 \times 10^{5}$ \\
Enterobacterium & & & & \\
Eubacterium & & $8.0 \times 10^{4}$ & & $7.2 \times 10^{2}$ \\
Candida & & $2.1 \times 10^{5}$ & $2.0 \times 10^{2}$ & $1.6 \times 10^{4}$ \\
Staphylococcus & $2.0 \times 10^{2}$ & & $3.0 \times 10^{2}$ & $4.0 \times 10$ \\
Peptostreptococcus & $2.0 \times 10^{5}$ & & & \\
Bacteroides & & & & $2.2 \times 10^{4}$ \\
Fusobacterium & & & & $1.8 \times 10^{4}$ \\
Veillonella & & & & $8.0 \times 10^{3}$ \\
Streptococcus & $7.5 \times 10^{5}$ & $8.0 \times 10^{2}$ & $9.5 \times 10^{5}$ & \\
Lactobacillus & & $7.0 \times 10$ & $1.1 \times 10^{4}$ & \\
Actinomyces & & & & \\
Actinobacillus & & $2.4 \times 10^{5}$ & $6.0 \times 10^{5}$ & $8.0 \times 10^{5}$ \\
Capnocytophaga & $5.0 \times 10^{3}$ & $7.0 \times 10^{4}$ & $2.0 \times 10^{5}$ & $1.4 \times 10^{4}$ \\
\hline
\end{tabular}

ており，やや正常像に近いピンク色を呈していた。さ らに, 約 1 力月半の周期で緩解期と増悪期を繰り返し ていた。

症例 2 では, 増悪期では, 前歯部においては, 主と
して, 辺縁歯肉のみの上皮が剝離し, 光沢をおび, 鮮 紅色を呈しており，付着歯肉には，あまりそのような 症状は認められなかったが, 臼歯部では, 付着歯肉に も剥離傾向が認められた。また, 緩解期では症例 1 と 
表 5 緩解期と増悪期における菌種（歯周ポケット）

\begin{tabular}{lcccc}
\hline & Case 1 & & Case 2 \\
& Remissive s. & Deteriorative s. & Remissive s. & Deteriorative s. \\
\hline $\begin{array}{l}\text { Bifidobacterium } \\
\text { Enterobacterium }\end{array}$ & $5.0 \times 10^{2}$ & & & \\
Eubacterium & & & $1.0 \times 10$ \\
Candida & $1.0 \times 10^{2}$ & & $1.5 \times 10^{2}$ & \\
Staphylococcus & & & & \\
Peptostreptococcus & $2.0 \times 10^{4}$ & & & \\
Bacteroides & $2.0 \times 10^{4}$ & $4.0 \times 10^{4}$ & & $5.0 \times 10^{3}$ \\
Fusobacterium & & & & \\
Veillonella & $1.0 \times 10^{4}$ & & & \\
Streptococcus & $5.0 \times 10^{4}$ & $5.0 \times 10$ & $3.5 \times 10^{5}$ & \\
Lactobacillus & & & & \\
Actinomyces & & & & \\
Actinobacillus & & $7.2 \times 10^{4}$ & $3.6 \times 10^{5}$ & $2.7 \times 10^{4}$ \\
Capnocytophaga & & $1.8 \times 10^{4}$ & $1.9 \times 10^{5}$ & $3.1 \times 10^{4}$ \\
\hline
\end{tabular}

同様に，前歯部および臼歯部ともに，前述の増悪期と 比較すると，辺縁歯肉および付着歯肉の光沢をおびた 鮮紅色の範囲が狭まってきていた。この患者では 1 カ 月程度の周期をもって緩解期と増悪期を繰り返してい た。

以上のように, 臨床的に, 症例 1 と 2 では, その病 状をあらわす部位あるいは周期こそ異なるが，明らか に，緩解期と増悪期とを繰り返し，しかもプラークを コントロールすることにより, 臨床症状の改善が認め られた。これらのことは先人達の報告とよく一致する ところである。

一方, 病理組織学的観察の光顕像では, 症例 1 お び 2 ともに，上皮突起は扁平化をきたして上皮組織は 薄くなり，また，過錯角化や過角化がみられ，上皮下 には著しいリンパ球の浸潤が認められた。薄くなった 上皮の基底細胞層下には微小な水疱形成がみられ，そ こには好中球や単核球が認められた。このように組織 学的に扁平苔痽の像を呈した。

Glickman et al.5) は慢性剝離性歯肉炎を 2 つの主要 な型, すなわち, 大水疮型と類苔癝型に分類している。 前者では, 乳頭状および網状の結合組織が, 浮腫, フィ ブリン，そして白血球の浸潤で置き換えられ，大水疱 が上皮一結合組織の接合部に形成され，上皮が結合組 織から持ち挙げられているのが特徵である。また, 後 者では，上皮の萎縮や，錯角化，基底細胞の空胞化と 上皮一結合組織接合部での小水疮の形成がみられ, 結 合組織にはリンパ球を主体とする慢性炎症が存在する
のがその特徵であるという。本研究の 2 症例ともに, 病理学的にみれば, 類苔癬型といえる。

電顕的に, 上皮細胞間隙には好中球やリンパ球様細 胞, amorphous substance がみられ，基底細胞と基底 板は分離し，その間にも amorphous substance が認め られた。また，基底細胞層付近の細胞にはデスモソー ムの数の減少がみられた。上皮下結合組織にはリンパ 球を主体とする炎症細胞浸潤があり,一部のリンパ球 の核は不規則になっていた。このような所見も，従前 よりの電顕観察結果 ${ }^{3,5,7)}$ と一致する。すなわち, 上皮 一結合組織の境界部に最も顕著な変化が起こり, 炎症 や上皮下水疮ないし大水疮が形成される。上皮基底層 には細胞間浮腫および細胞内変性がみられ，基底板は 密度や幅が不規則であり，変性した基底上皮細胞から ちぎれて結合組織に付着する傾向がある。離れた結合 組織が大水疮の底部を形成し, 大水疱には時に基底板 が欠落している。大水疮は顆粒物質, 細胞質破片, 赤 血球などを含んでいる。小水疱状部位に含まれている 微細な原線維状の物質や顆粒状物質は, 結合組織中に みられるという報告 ${ }^{3,6,7)}$ があるが，本症例の電顕所見 も前述の光顕所見と同様に以前の報告とよく一致する ところである。

緩解期と増悪期における唾液, 歯肉溝滲出液, 舌苔 およびポケット内の歯垢の細菌数は，両時期の間に関 連性がなかった。また，緩解期と増悪期における細菌 の酸素要求性および細胞形態に基づく細菌の分布を比 較すると, 両症例とも, 数值の変化は認められたが, 
一定の傾向はみられなかった。ただ, 増悪期になると, 好気性菌が若干増える傾向にあった。一方，緩解期と 増悪期の菌種と菌数は, 両症例ともに, 変化したが, 一定の傾向は認められなかった。このことから慢性剝 離性歯肉炎のその症状の緩解期と増悪期とでは口腔内 の細菌叢が異なるのではないかと考えられるので, 培 養による総菌数あるいはその細菌叢を観察したが，一 定の傾向はみられなかった。したがって，今後は症例 数を増やすとともに, 近年, 認められつつある自己免 疫学的な面 ${ }^{8 \sim 10)}$ からの検討もしていきたいと考えてい る。

\section{結 論}

慢性剝離性歯肉炎患者の臨床的観察, あるいは歯肉 の biopsy を行い光顕的および電顕的に観察するとと もに, 唾液, 歯肉溝滲出液, 舌苔およびポケット内の 歯垢を細菌学的に検討した結果，つぎの結論を得た。

1. 臨床的に, 増悪期では, 上皮は剥離し, 光沢を おび, 鮮紅色を呈していた。また, 緩解期では, 増悪 期と比較して, 光沢をおびた鮮紅色の範囲も狭かった。 症例 1 は約 1 力月半, 症例 2 では約 1 力月の周期で緩 解期と増悪期を繰り返していた。

2. 病理組織学的観察の光顕像では, 症例 1 および 2 ともに, 上皮突起は扁平化をきたして上皮組織は薄 くなり,また，過錯角化がみられ，上皮下には著しい リンパ球の浸潤が認められた。基底細胞層付近の細胞 間隙は拡張し，そこにリンパ球や出血がみられた。ま た, 上皮の基底細胞層下に微小な水疱形成がみられ, そこには好中球や単核球が認められた。また, 電顕的 に, 上皮細胞間隙には好中球やリンパ球様細胞, amorphous substance がみられ，基底細胞と基底板は分離 し，その間にも amorphous substance が認められた。 また, 基底細胞層付近の細胞にはデスモソームの数の 減少がみられた。上皮下結合組織にはリンパ球を主体 とする炎症細胞浸潤があった。

3. 細菌学的観察における, 唾液, 歯肉溝滲出液,
舌苔およびポケット内の歯垢の緩解期と増悪期におけ る細菌数は, 両時期の間には関連性がなかった。また, 緩解期と増悪期における酸素要求性および細胞形態に よる細菌分布を比較すると, 両症例を通じて, 数值の 変化が認められたが, 一定の傾向はみられなかった。 ただ，増悪期になると，好気性菌が若干増える傾向に あった。一方, 緩解期と増悪期の菌種と菌数は, 両症 例ともに, 変化したが, 一定の傾向は認められなかっ た。

\section{文献}

1）日本歯周病学会編：改訂 歯周疾患治療指針，東京， 1989, 73.

2）石川 純, 姫野 宏:ペリオドンティクスの臨床 慢性剝離性歯肉炎, 歯界展望, 別冊 : 389-394, 1977.

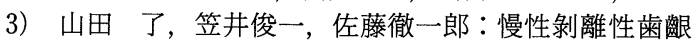
炎に関する病理組織学的検索, 日歯周誌, $22: 267-$ 282, 1980.

4) Engel, M.B., Ray, H.G. and Orban, B. : The pathogenesis of desquamative gingivitis. A disturbance of the connective tissue ground substance. J. Dent. Res., 29 ; 410-418, 1950.

5) Glickman, I. and Smulow, J.B. : Histopathology and histochemistry of chronic desquamative gingivitis. Oral Surg. Oral Med. Oral Pathol., 21 : 325-332, 1966.

6) Whitten, J.B. : The fine structure of desquamative stomatitis. J. Periodontol., 39: 75-80, 1968.

7) Brusati, R. and Bracchetti, A.: Electron microscopic study of chronic desquamative gingivitis, J. Periodontol., 40 : 388-397, 1969.

8) Laskaris, G., Demetriou, N. and Angelopoulos, A. : Immunofluorescent studies in desquamative gingivitis. J. Oral Pathol., $10: 398-407,1981$.

9) Nisengard, R. and Neiders, M. : Desquamative lesions of the gingiva. J. Periodontol., $52: 500^{-}$ 510, 1981.

10) Porter, S.R., Scully, C., Midda, M., et al. : Adult linear immunoglobulin A disease manifesting as desquamative gingivitis. Oral Surg. Oral Med. Oral Pathol., $70:$ 450-453, 1990.

連絡先：

大阪歯科大学歯周病学講座

₹ 540 大阪市中央区大手前 1-5-31 